\title{
Productivity Improvement in Steering Knuckle Machining Line Using Lean Principles
}

\author{
N. Sathiya Narayanan ${ }^{1}$, R. Kumar ${ }^{1}$, A.Maria Jackson ${ }^{1}$, K. Nataraj ${ }^{2}$ \\ Assistant Professor, Mechanical Engineering Dept., Saranathan College of Engineering, Tamil Nadu, India, Trichy ${ }^{1}$ \\ UG Student, Mechanical Engineering Department, Saranathan College of Engineering Tamil Nadu, India, Trichy²
}

\begin{abstract}
To enhance the productivity and quality of products many firms are practicing the lean manufacturing concepts. Value Stream Mapping (VSM) is one of the lean tools to visualize the hidden waste and its sources. This paper describes the lead time reduction of steering knuckles carried out at XYZ organization in Tiruppur located in South India. On observing the present system of steering knuckle production, the current lead time was calculated and found to be 22.70 minutes for producing two components simultaneously in $\mathrm{CNC}$ machines and their current production rate is 619 components per day against the customer demand of 648 components per day. A VSM is drawn to find out the value and non-value added activities involved in current production floor. Then, a Future Value Stream Map is developed to design a lean process flow through the elimination of the root causes for the wastes and through process improvements. This paper uses the VSM technique thereby helps the management to reduce the production lead time of steering knuckle and to fulfill the customer demands.
\end{abstract}

Keywords: Lean Manufacturing, Value Stream Mapping, Steering Knuckle, Lead time, Customer Demand.

\section{INTRODUCTION}

The objective of Lean Manufacturing is to reduce waste and highly responsive to customer demand while producing quality products in the most efficient and economical manner. The core idea behind lean manufacturing is maximizing customer value while minimizing waste, thereby achieving manufacturing excellence through the creation of more value with fewer resources. A lean organization understands customer value and focuses its key processes to continuously increase it. The ultimate goal is to provide perfect value to the customer through a perfect value creation process that has zero waste. Eliminating waste along entire value streams, instead of at isolated points, creates processes that need less human effort, less space, less capital and less time to make products and services at far less costs and with much fewer defects, compared with traditional business systems. Lean can be applicable to any process not only to the manufacturing. Value is defined as a product or a service for which customer desires.

In simple lean is "Creating value with less work". Lean manufacture has a comprehensive set of elements, rules and tools that focus on the elimination of waste and the creation of value. It aggressively seeks to eliminate all non-value added activity and tries to instill a philosophy of continuous incremental improvement. Lean manufacturing also means increasing the speed by reducing the process time.

Value-stream mapping is a pencil and paper tool that helps you to see and understand the flow of material and information as a product makes its way through the value stream. Value Stream Mapping can also be applied to the process industry as well as to the service sector. In this paper, VSM technique is applied to the flow line manufacturing process in the context of production improvement. The main objectives of this paper is to

reduce the non value added activities, minimizing the takt time, maximizing machine, men and space utilization.

\section{LITERATURE REVIEW}

Russel and Taylor, (1999) explained that the major purposes of the use of lean manufacturing are to increase productivity, improve product quality and manufacturing cycle time, reduce inventory, reduce lead time and eliminate manufacturing waste. To achieve these, the lean manufacturing philosophy uses several concepts such as one-piece flow, kaizen, cellular manufacturing, synchronous manufacturing, inventory management, pokayoke, standardized work, work place organization, and scrap reduction to reduce manufacturing waste.

Khaswala et al (2001) explained the basic concepts of Value stream mapping and how to implement them in case of multiple flow value stream mapping that merge in case of a complex product. Abdulmalek and Rajagopal (2006) presented lean manufacturing principles being applied to a steel mill. The lean manufacturing tool of value stream mapping has been used to map the scenarios. The paper also described simulation models which were developed using lean manufacturing principles and also analyzed the possible benefits.

Scherrer Rathje et al. (2009) identified the major criteria and conditions that lead to either lean success or failure. They found the sources to failure like the lack of senior management commitment, lack of interest and low acceptability of workers for changes. Saurin and Ferreira (2009) have presented guidelines for assessing lean production impacts on working conditions either at a plant or a departmental level, which were tested on a harvester assembly line in Brazil.

McDonald et al (2010) explained wasteful steps that have to be eliminated and flow can be introduced in the 
remaining value-added processes. The concept of flow is to make parts ideally one piece at a time from raw materials to finished goods and to move them one by one to the next workstation with no waiting time in between. William et al (2011) presented the use of value stream mapping tool in identifying, quantifying and minimizing major wastes in a bread manufacturing set-up. The case study shows how the VSM tool was used to identify and reduce defects, unnecessary inventory, and motion. Gurumurthy and kodali (2011) presented simulation of models which have been modified by using Lean manufacturing principles and elements. The impact of implementation of lean manufacturing elements on the company's performance was also analyzed.

\section{PROCESS DETAILS}

This study concentrates on the steering knuckle of a car. After the process in foundry shop, the unfinished product will be shifted to machining line.In first machine boring, drilling, face finishing, tapping of caliber arm will be carried out. After this, Face milling and spot facing will be carried out for UBJ (Upper Bolt Joint) in Machine 2.

Machine 3 carry out the spot facing for LBJ (Lower Bolt Joint).Then milling, drilling and reaming is done for tie rod arm in Machine 4. At the end spot facing, tapping and chamfering is done on the whole. Now it has been sent for final inspection. Dimensions and other parameters are inspected and sent for delivery.

\section{A. Data Collection}

Data are collected and recorded for the actual production on a shift basis. It helps to find out the major time consuming operations, value added and non-value added activities. It also helps to visualize the root causes and possible solutions for the problems.

\section{B. Value \& Non-Value added activities}

The value we add to your products is what convinces your customers to buy them. Non-value-added activities add costs to your product without enhancing the value. Here the machining operations are considered as value added to the product, while the inspection, delay between the machines considered as non- value added activities.
The contribution of each process to the overall manufacturing time, the value added timing and non-value added timing is described in the table 1 . Here, in the steering knuckle production line, the value added contributes $70.8 \%$, whereas the non-valued activities contributed $29.2 \%$.

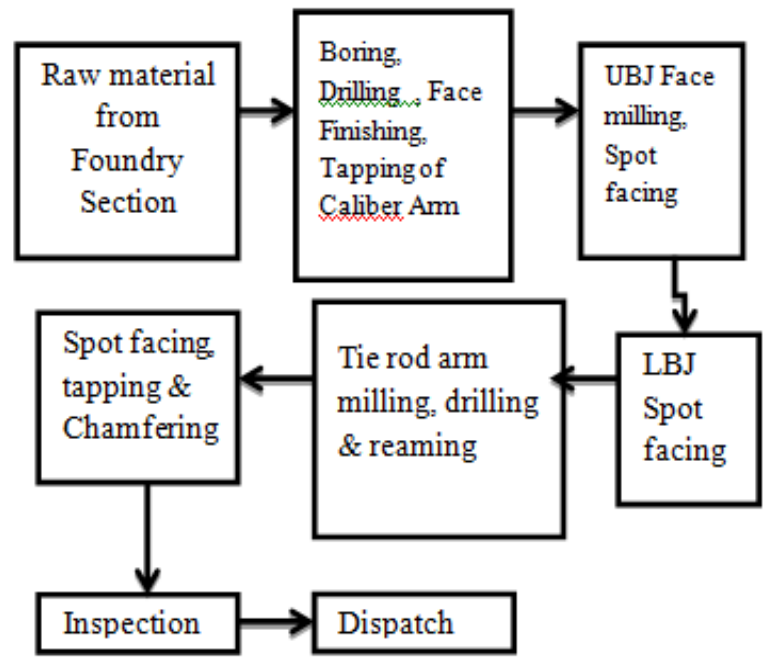

Fig.1. Process Flow diagram of Steering Knuckle

\section{CURRENT VALUE STREAM MAPPING}

The firm under study employs 500 personnel including workers, supervisors, engineers and top management. It operates with 10000 square feet of space. The case study is dealt with steering knuckle manufacturing process and it is used in automobiles. The manufacturing of steering knuckle is flow line manufacturing process.

All the data for current state map were collected with the consultation to workers, supervisors, engineers and managers. The calculation of existing TAKT time is given below with the collected data from the firm's manager. The demand per day of steering knuckle is 648 numbers, current production capacity per day is 619 numbers, the effective number of working days of the firm per month is 30 and number of shifts per day is 3. Shift 1 \& 2 constitutes of $8 \mathrm{~h} 30$ minutes, whereas shift 3 constitute 7 hours.

TABLE I DATA COLLECTION OF STEERING KNUCKLE PRODUCTION LINE

\begin{tabular}{|l|c|c|c|c|}
\hline Process & Time(sec) & Contribution\% & Value Added (sec) & Non-Value Added (sec) \\
\hline Receiving Forged Components & 60 & 4.4 & & 60 \\
\hline Inward inspection & 50 & 3.67 & & 50 \\
\hline Delay & 5 & 0.36 & & \\
\hline $\begin{array}{l}\text { Boring, Face Finishing, Tapping, } \\
\text { Milling \& Drilling }\end{array}$ & 450 & 33.0 & & 650 \\
\hline Inspection of Process 1 & 65 & 4.8 & & \\
\hline UBJ Face Milling \& Spot Facing & 236 & 17.3 & 236 & \\
\hline Inspection of Process 2 & 42 & 3.1 & & 26 \\
\hline LBJ Spot Facing & 122 & 9.0 & & \\
\hline Inspection of Process 3 & 26 & 1.9 & & \\
\hline $\begin{array}{l}\text { Tie Rod arm Milling, Drilling and } \\
\text { Reaming }\end{array}$ & 116 & 8.5 & & 38 \\
\hline Inspection of Process 4 & 38 & 2.8 & & \\
\hline Spot Facing, Tapping \& Chamfering & 40 & 2.9 & & \\
\hline Machine 5 to Inspection area & 22 & 1.6 & & \\
\hline Final Inspection & 90 & 6.6 & & \\
\hline Total Time & $\mathbf{1 3 6 2}$ & $\mathbf{1 0 0 \%}$ & $\mathbf{9 6 4}$ & \\
\hline
\end{tabular}


TAKT time $_{\text {Existing }}=$ Available working time per day

Production capacity per day

$$
=\frac{7.5}{(216 / 30)}
$$$$
=1.041 \mathrm{hrs}
$$

TAKT time $_{\text {Expected }}=$ Available working time per day

Production capacity per day

$$
=\frac{7.5}{(230 / 30)}
$$

$=0.978 \mathrm{hrs}$

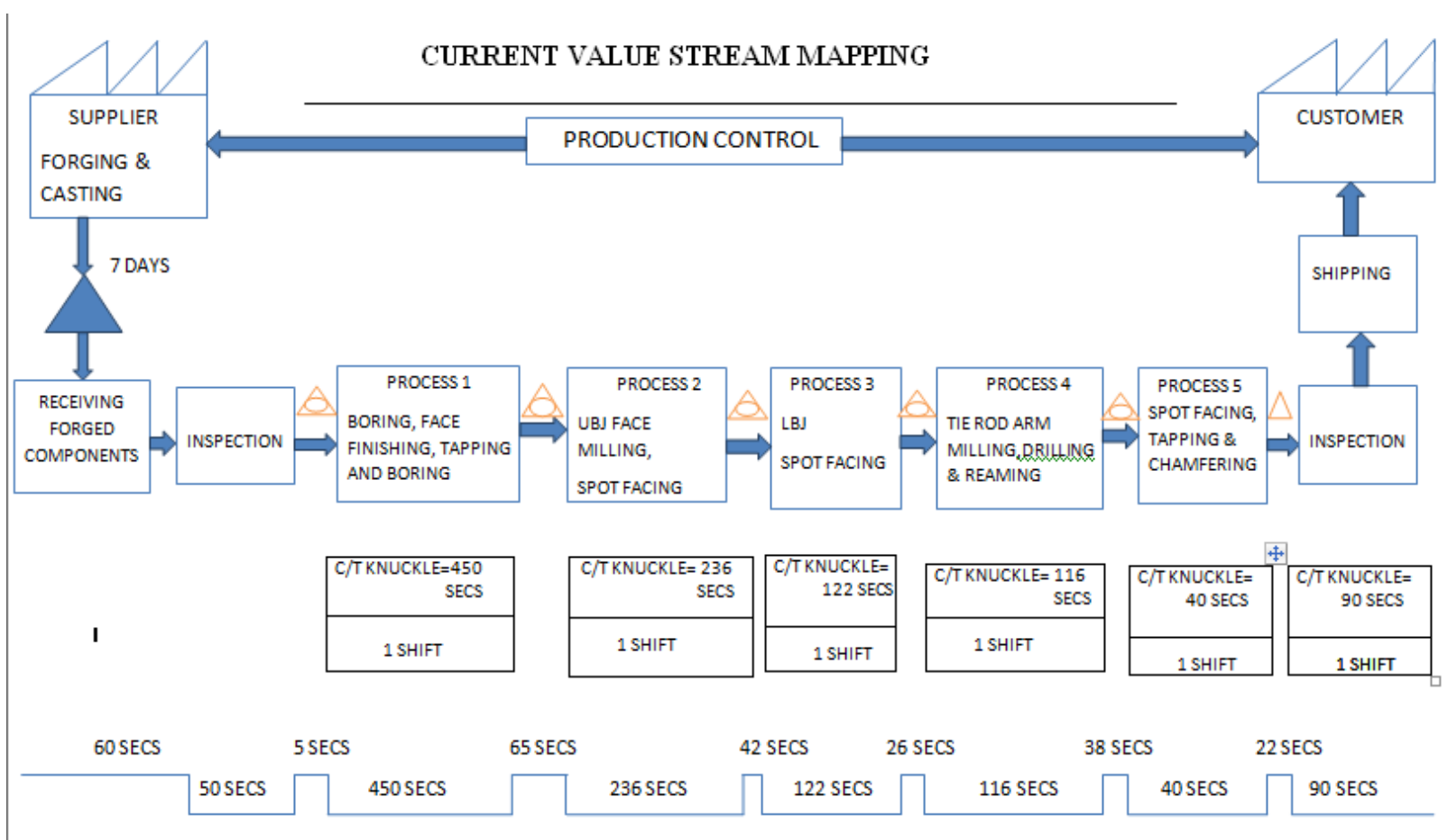

Fig.2. Current Value Stream Map

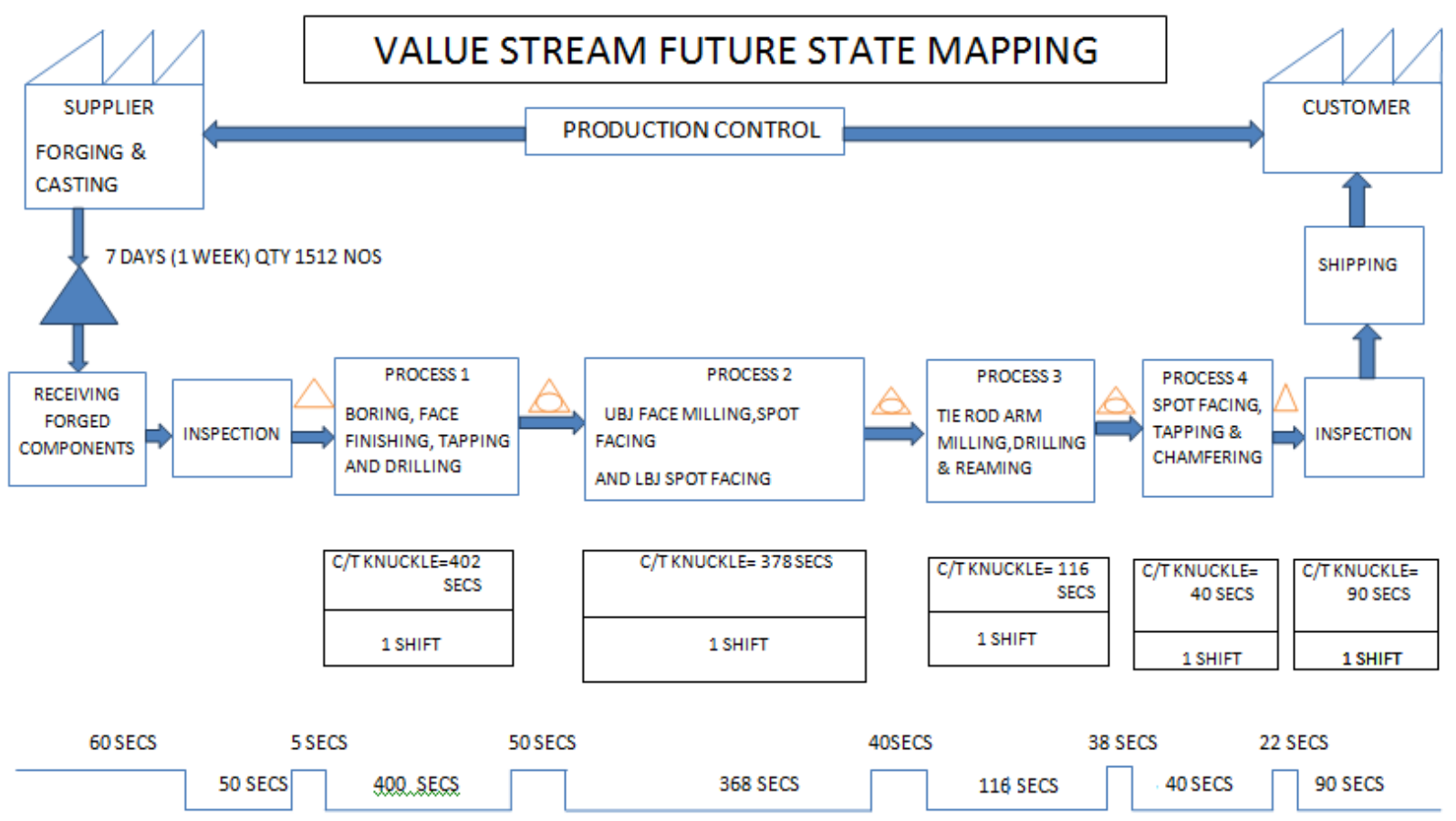

Fig.3. Future State Value Stream Map 


\section{ANALYSIS OF CURRENT STATE MAP}

- The unfinished component from foundry shop is been inspected before the machining process. Now the component will be waiting for to enter the process 1 where boring, drilling, face finishing and tapping of caliber arm is done.

- The time period for the Process 1 is $450 \mathrm{sec}$.

- Then it enters the process 2 after the inspection and delay time of $65 \mathrm{secs}$ where spot facing and face milling of upper bolt joint is done.

- The time period for process 2 is $236 \mathrm{sec}$.

- Then it enters the process 3 after the inspection and delay time of $42 \mathrm{sec}$ where spot facing of lower bolt joint is done.

- The time period for the Process 3 is $122 \mathrm{sec}$.

- Then it enters the process 4 after the inspection and delay time of 26 secs where milling, drilling and reaming of tie rod arm is carried out.

- The time period for the Process 4 is 116 sec.

- Then it enters the process 5 after the inspection and delay time of 38 secs where spot facing tapping and chamfering is done.

\section{FUTURE STATE VALUE STREAM MAP}

- The firm's current production line has been analyzed by using value stream mapping tool of lean manufacturing.

- The value and non-value added activities of the production line were segregated and their considerations contributions are calculated.

- Here, we suggest reducing the unnecessary inspections in the production line.

- It also suggested to combine the process $2 \& 3$ (UBJ \& LBJ) in a single machine which will eliminate the need for the machine 3 and at the same time, the labour of process 3 can be used for inspecting the components coming out from process 1 .

- By combining process $2 \& 3$, the inspection between 2 and 3 processes can be eliminated.

- The clamping of work pieces in all the process can be made by hydraulic grippers.

- It's our perception that by implementing these suggestions the firm may improve the production rate of steering knuckle to some extent to meet their customer demands.

TABLE II ANALYSIS OF FUTURE STATE MAP

\begin{tabular}{|l|c|c|c|c|}
\hline \multicolumn{1}{|c|}{ Process } & Time(sec) & Contribution\% & $\begin{array}{c}\text { Value } \\
\text { Added }\end{array}$ & $\begin{array}{c}\text { Non-Value } \\
\text { Added }\end{array}$ \\
\hline Receiving Forged Components & 60 & 4.7 & & 60 \\
\hline Inward inspection & 50 & 3.9 & & 50 \\
\hline Delay & 5 & 0.4 & & 5 \\
\hline $\begin{array}{l}\text { Boring, Face Finishing, Tapping, Milling \& } \\
\text { Drilling }\end{array}$ & 400 & 31.3 & 400 & \\
\hline Inspection of Process 1 & 50 & 3.9 & & 50 \\
\hline $\begin{array}{l}\text { UBJ Face Milling \& Spot Facing \& LBJ Spot } \\
\text { Facing }\end{array}$ & 368 & 28.8 & 368 & \\
\hline Inspection of Process 2 & 40 & 3.1 & & 40 \\
\hline Tie Rod arm Milling, Drilling and Reaming & 116 & 9.1 & 116 & \\
\hline Inspection of Process 3 & 38 & 3.0 & & 38 \\
\hline Spot Facing, Tapping \& Chamfering & 40 & 3.1 & 40 & \\
\hline Machine 4 to Inspection area & 22 & 1.7 & & 22 \\
\hline Final Inspection & 90 & 7.0 & & 90 \\
\hline Total Time & $\mathbf{1 2 7 9}$ & $\mathbf{1 0 0 \%}$ & $\mathbf{9 2 4}$ & $\mathbf{3 5 5}$ \\
\hline
\end{tabular}

TABLE III RESULTS COMPARSION

\begin{tabular}{|c|c|c|c|c|c|c|c|}
\hline \multirow[b]{2}{*}{ VSM } & \multirow{2}{*}{$\begin{array}{l}\text { Total Manufacturing } \\
\text { Time for } 2 \\
\text { components (sec) }\end{array}$} & \multirow{2}{*}{$\begin{array}{l}\text { Value } \\
\text { Added } \\
\%\end{array}$} & \multirow[b]{2}{*}{$\begin{array}{l}\text { Non-Value } \\
\text { Added } \%\end{array}$} & \multicolumn{3}{|c|}{ No. of Components } & \multirow[b]{2}{*}{$\begin{array}{c}\text { Total No. of } \\
\text { Components/day }\end{array}$} \\
\hline & & & & Shift 1 & Shift 2 & Shift 3 & \\
\hline $\begin{array}{c}\text { Current } \\
\text { State Map }\end{array}$ & 1362 & 70.8 & 29.2 & 216 & 216 & 187 & 619 \\
\hline $\begin{array}{c}\text { Future State } \\
\text { Map }\end{array}$ & 1279 & 72.24 & 27.76 & 226 & 226 & 193 & 645 \\
\hline
\end{tabular}




\section{RESULT AND DISCUSSIONS}

From the table 3 it's clear that the total manufacturing time required for 2 components was $1362 \mathrm{sec}$ in the current production line, the Value added and Non-Value added activities contributes $70.8 \%$ and $29.2 \%$ respectively. By implementing the future state map we can reduce the total manufacturing time for 2 components from 1362 seconds to 1279 seconds. Similarly the Value added and Non-Value added also reduced to $72.2 \%$ and $27.76 \%$ respectively. The no. of components produced can be increased from 619 to 645 to meet the customer demand.

\section{ACKNOWLEGMENT}

Thanking Our Almighty. We sincerely thank our management and our colleagues of Saranathan College of Engineering, Trichy, Tamil Nadu, INDIA for the support and motivation. We thank the organization those given the opportunity to us to prove ourselves.

\section{REFERENCES}

[1] Russell, R.S. and Taylor, B.W., "Operations management", $2^{\text {nd }}$ edition, Uppre Saddle River, NJ: Prentice Hall, 1999.

[2] Khaswala, Z.N., and Irani, S.A., 2001 'Value Network Mapping (VNM): Visualization and Analysis of Multiple Flows in Value Stream Maps', Proceedings of the Lean Management Solutions Conference, St. Louis, Missouri, United states of America, pp.4763.

[3] Abdulmalek, F.W. and Rajgopal, J., 2006 'Analyzing the benefits of lean manufacturing and value stream mapping vi simulation: $A$ process sector case study', International Journal of Production Economics, Vol.107, pp. $223-236$.

[4] Maike Scherrer-Rathje, Todd A. Boyle,Patricia Deflorin "Lean, take two! Reflections from the second attempt at lean implementation" Business Horizons (2009) 52, 79-88, ScienceDirect, Elsevier

[5] Saurin, T.A. and Ferreira, F.C. (2009) 'The impacts of lean production on working conditions:a case study of a harvester assembly line in Brazil', International Journal of Industrial Ergonomics, Vol. 39, p.403-412

[6] McDonald TE, Aken V, Butler R. Integration of Simulation and Value Stream Mapping in Transformation to Lean Production, IIE Annual Conference 2010.

[7] William C. Thorsen, A book on Value Stream Mapping \& VM, General Motors Corporation

[8] Gurumurthy, A. and Kodaly, R., 2011 'Design of lean manufacturing systems using value stream mapping with simulation: A case study', Journal of Manufacturing Technology Management, Vol. 22 Issue 4, pp.444 - 473.

[9] Wong, Y. C., Wong, K. Y., Approaches and Practices of Lean Manufacturing: The Case of Electrical and Electronics Companies, African Journal of Business Management 2011;5:2164.

[10] Doolen, T. L.,Hacker, M. E., A Review of Lean Assessment In Organizations: An Exploratory Study of Lean Practices By Electronics Manufacturers, Journal of Manufacturing Systems 2005;24:55.

[11] Nordin, N., Deros, B. M.,Wahab, D. A., A Surveyon Lean Manufacturing Implementation In Malaysian Automotive Industry, International Journal of Innovation, Management and Technology 2010;1:374.

[12] Sanchez, A. M., Perez, M. P.,2001. Lean Indicators and Manufacturing Strategies, International Journal of Operation and Production Management 21:1433. 